\title{
OSTEOMETRIC ESTIMATION OF SEX FROM MASTOID TRIANGLE IN MALAYSIAN POPULATION
}

\section{ABDELNASSER IBRAHIM ${ }^{1,2}$, ASPALILAH ALIAS ${ }^{1,3}$, MOHAMED SWARHIB SHAFIE ${ }^{1}$, SRIJIT DAS ${ }^{4}$, FARIDAH MOHD NOR ${ }^{1 *}$}

${ }^{1}$ Forensic Unit, Department of Pathology, Universiti Kebangsaan Malaysia Medical Centre, Jalan Yaacob Latif, Bandar Tun Razak, 56000 Kuala Lumpur, Malaysia. ${ }^{2}$ Department of Forensic Medicine and Clinical Toxicology, Faculty of Medicine, Al Azhar University, Almokhayam Aldaem Street, Cairo, Egypt. ${ }^{3}$ Department of Basic Sciences and Oral Biology, Faculty of Dentistry, Universiti Sains Islam Malaysia, Tingkat

15, Menara B, Persiaran MPAJ, Jalan Pandan Utama, Pandan Indah, 55100 Kuala Lumpur, Malaysia. ${ }^{4}$ Department of Anatomy, Universiti Kebangsaan Malaysia Medical Centre, Jalan Yaacob Latif, Bandar Tun Razak, 56000 Kuala Lumpur, Malaysia. Email: mnfaridah@gmail.com

Ref: https://innovareacademics.in/journals/index.php/ajpcr/article/view/25986/15201

\section{ABSTRACT}

Objective: Determination of sex is one of the most important parameters for conducting biological profile of unknown skeletal remains in anatomical anthropology and forensic medicine. Mastoid bone is useful for the identification of sex, as it is the most protected bone and is resistant to damage, due to its anatomical position at the base of the skull. The aim of this study was to develop new equation for the estimation of sex from mastoid triangle in the Malaysian population.

Methods: About 10 parameters were studied on 388 computed tomography scans of crania in 231 males and 157 females. The parameters comprised three sides of mastoid triangle, its perimeter and area on both sides. T-test was used to compare between the right and left sides and between males and females. Stepwise discriminant function was used to reveal the best discriminatory parameter and its classification accuracy.

Results: Comparison of means by T-test revealed no difference between the right and left sides in both sexes. T-test showed a significant difference between males and females for all parameters. Perimeter of mastoid triangle was found to be the best parameter by stepwise discriminant analysis. The equation based on perimeter of mastoid triangle was developed with $84.4 \%$ classification accuracy.

Conclusion: The developed equation could be used to assess sexual dimorphism of fragmented Malaysian crania with intact mastoid region. The achieved cross-validated classification was relatively high compared to that in other previous studies.

Keywords: Mastoid, Sex, Computed tomography scan, Anthropology, Forensic.

Erratum of the manuscript no 25986 published in July issue 2018

Old Authors-

ABDELNASSER IBRAHIM1,2, ASPALILAH ALIAS1,3, MOHAMED SWARHIB SHAFIE1, SRIJIT DAS4, FARIDAH MOHD NOR1*

Old Affiliations-

1Forensic Unit, Department of Pathology, Universiti Kebangsaan Malaysia Medical Centre, Jalan Yaacob Latif, Bandar Tun Razak, 56000 Kuala Lumpur, Malaysia. 2Department of Forensic Medicine and Clinical Toxicology, Faculty of Medicine, Al Azhar University, Almokhayam Aldaem Street, Cairo, Egypt. 3Department of Basic Sciences and Oral Biology, Faculty of Dentistry, Universiti Sains Islam Malaysia, Tingkat 15, Menara B, Persiaran MPAJ, Jalan Pandan Utama, Pandan Indah, 55100 Kuala Lumpur, Malaysia. 4Department of Anatomy, Universiti Kebangsaan Malaysia Medical Centre, Jalan Yaacob Latif, Bandar Tun Razak, 56000 Kuala Lumpur, Malaysia.

New Authors-

ABDELNASSER IBRAHIM1,2, ASPALILAH ALIAS1,3, MOHAMED SWARHIB SHAFIE1,SRIJIT DAS4,FARIDAH MOHD NOR1*, NURLIZA ABDULLAH5,MOHAMAD HELMEE MOHAMAD NOOR6.

New Affiliations-

1Forensic Unit, Department of Pathology, Universiti Kebangsaan Malaysia Medical Centre, Jalan Yaacob Latif, Bandar Tun Razak, 56000 Kuala Lumpur, Malaysia. 2Department of Forensic Medicine and Clinical Toxicology, Faculty of Medicine, Al Azhar University, Almokhayam Aldaem Street, Cairo, Egypt. 3Department of Basic Sciences and Oral Biology, Faculty of Dentistry, Universiti Sains Islam Malaysia, Tingkat 15, Menara B, Persiaran MPAJ, Jalan Pandan Utama, Pandan Indah, 55100 Kuala Lumpur, Malaysia. 4Department of Anatomy, Universiti Kebangsaan Malaysia Medical Centre, Jalan Yaacob Latif, Bandar Tun Razak, 56000 Kuala Lumpur, Malaysia. 5National Institute of Forensic Medicine, Hospital Kuala Lumpur, Ministry of Health Malaysia, Jalan Pahang, 50586 Kuala Lumpur, Malaysia. 6Radiology Department, Hospital Kuala Lumpur, Ministry of Health Malaysia, Jalan Pahang, 50586 Kuala Lumpur, Malaysia. 